\title{
'We all miss you': Enrico Berlinguer in post-Berlin Wall Italy. *
}

\author{
Philip Cooke and Gianluca Fantoni
}

A t the time of his death, in 1984, communist leader Enrico Berlinguer's political appeal and popularity was at its apogee in Italy. Deputy leader of the Italian Communist Party (PCI) from 1969, and then leader from 1972 until his death, Berlinguer had been one of the most loved politicians of the history of the Italian Republic, a man of recognised unselfishness whose integrity, as Donald Sassoon memorably put it 'was doubted only by those who had none'. ${ }^{1}$ Under his leadership, the party had reached the peak of its electoral popularity, winning $34.4 \%$ of the votes at the national elections of 1976 . Arguably, because of the emotion produced in the country by his dramatic death - he suffered a massive stroke while delivering a speech at an electoral meeting - the PCI gained the only victory over Democrazia Cristiana (DC) in its history, at the European elections of June 1984. More than one million people attended Berlinguer's funeral in Rome. ${ }^{2}$

That event, broadcast live by the Italian public television network, appears nowadays like the swan song of Italian communist pride, before the PCI's electoral and political decline of the second half of the 1980s. A few years later the Italian Communist Party ceased to exist, following the decision to change the name of the party taken at the XXth and last congress of the PCI, in 1991. The PCI was no more, but Enrico Berlinguer's reputation had just begun to soar and it would increasingly flourish, in a range of political and cultural spaces, in the years to come. In fact, it is possible to speak of an enduring 'nostalgia for Berlinguer' in present- day Italy. This nostalgia is felt not only by former communist militants and voters, as could be expected, but also by many citizens and 
political commentators who have little in common with the history of Italian communism. The memory of Berlinguer has also been the object of a struggle, as different political players have tried to capitalise on his legacy, for different purposes. This paper analyses the posthumous vicissitudes of former communist leader Enrico Berlinguer from 1991 onwards, and examines the struggle over his memory and political legacy. It uses a range of sources in order to offer a novel perspective on an individual whose 'sepulchral charisma' has yet to be investigated by scholars of the PCI.

A reversal of fortune for a deceased communist leader is not a unique phenomenon in present-day Europe. In fact, parallels could be found, especially in the former communist world. ${ }^{3}$ However, it is quite uncommon to witness such a spectacular comeback by a former communist leader in the Western world. The thesis of this paper if that the nostalgia for Berlinguer in post-Berlin Wall Italy is rooted in a number of unresolved issues affecting Italian political life from 1991 onwards, and fuelling Italy's overheated political debate. The inability of the Italian post-communist left to come to terms with its past is probably the most resounding of these issues. The pursuit of alternative solutions by many left-wing commentators to the present political and economic crisis the country is experiencing, the contempt towards the post-communist left by right-wingers as well as by populist movements, and the vexed relationship between Italian politicians and their constituencies are also factors which have led to the positive reassessment of Berlinguer's political legacy and personality. Berlinguer has become to many the symbol of virtually everything that used to be right and is now wrong in Italy, the background against which to judge today's politicians and their policies in order to expose their shortcomings, the universal second system of comparison of post-Berlin Wall, post-globalisation Italy.

The end of the PCI was extraordinarily traumatic for the party's militants and voters. Yet it was an inevitable and necessary step to take: after the collapse of the communist regimes in Eastern Europe, the word communist was utterly discredited, while the very idea that a communist party could win an election and rule a European country sounded simply absurd. However, the process leading to the creation of the postcommunist Partito Democratico della Sinistra (Democratic Party of the 
Left or PDS), was anything but painless, and rather disruptive. Following the decision by the majority to change the name of the party, communist hard-liners promoted a split, which resulted in the creation of the Partito della Rifondazione Comunista (Communist Refoundation Party or PRC). This dramatic political reorganisation of the Italian left had serious consequences on the electoral plane. At the election of 1992, the sum of the votes won by the PDS and the PRC did not match the already disappointing results of the PCI in the elections of 1987. In fact, the PCI heirs lost about 1.5 million votes. Two years later, the electoral coalition formed by PDS and PRC suffered another debacle against the newly created Forza Italia! led (and owned) by media tycoon Silvio Berlusconi. In the eyes of the militants, it seemed like post-communist leaders had fragmented and partially dispersed the electoral consensus laboriously built by the PCI in over fifty years. However, things were even worse on the cultural and social planes. As pointed out by David I. Kertzer, the wholesale jettisoning of the party's symbolic apparatus, beginning with the name of the party, had far reaching consequences at grassroots level. ${ }^{4}$ It broke apart that sense of belonging to a common cultural and political horizon which traditionally kept militants together; it pushed many militants to political inactivity by depriving them of a common purpose; it left each and every communist with the sense of an unrecoverable defeat. ${ }^{5}$

In this context, history became paramount, as former militants and voters felt like their own biographies were inseparably intertwined with the history of the PCI. If the present was disappointing, the future anything but promising, they needed at least to be proud of their history, and of the history of the PCI. And yet, it was hardly a favourable moment to be proud of PCI's history. In fact, right at the beginning of the 1990s, the entire history of the Italian Communist Party came under scrutiny in a new historiographical current aimed at presenting the PCI as a sort of fifth column, serving the interests of the Soviet Union throughout the Republican era. The most illustrious victim of this historiographical reassessment, which was to some extent aimed at jeopardizing the electoral chances of the post-communist left, was the other great leader of the Italian Communist Party, Palmiro Togliatti, who had led the PCI from 1930 to 1934, and then uninterruptedly from 1938 to 1964. 
As early as 1991, Togliatti was the target of relentless attacks on the historiographical plane, by right-wing historians, as well as by journalists and politicians (including Silvio Berlusconi), who accused him of having been nothing but a henchmen of Stalin, a slave carrying out policies dictated by the Soviet leadership. ${ }^{6}$ The faltering and awkward reactions to such allegations by left-wing historians and politicians only exacerbated the situation, making the once beloved Togliatti an object of political embarrassment.

Of course, the Italian post-communists could still boast the intellectual achievements of Antonio Gramsci, one of the greatest Marxist thinkers of all time, who had never found himself in a position of power, and had died in 1937 as a result of his long imprisonment in fascist jails. And yet, the political and cultural fortune of the Sardinian thinker had faded in Italy around the end of the 1970s, when it became clear that the PCI had failed to attain the cultural and political hegemony that Gramsci had envisaged for the party he had co-founded in the early 1920s. ${ }^{7}$ The rather fraudulent exploitation of Gramsci's writings made by Palmiro Togliatti had also played a part in the decline of Gramsci's popularity over the years. ${ }^{8}$ The other leaders of the party such as Luigi Longo (1964-1972) or Alessandro Natta (1984-1988) lacked the charisma, and they had left too little a mark on the party history to be remembered as anything more than segretari di transizione (transitional leaders). A more detailed analysis is needed in order to understand why the last of the PCI secretaries, Achille Occhetto (1988- 1991), soon went into political oblivion. Occhetto had certainly played a decisive role in both the history of the PCI and the PDS. He was the leader who courageously and as far as we know as a result of his own initiative, took the decision to change the party name. He was the first leader of the PDS who had led the coalition of the left in an electoral struggle against the emergent political phenomenon of Berlusconi and, although defeated, had at least managed to win back some of the votes the PDS had lost in the previous elections. However, his name was indissolubly tied to a phase the post-communist leaders wanted to forget as soon as possible, a phase characterised by disruptive splits, electoral defeats, and political humiliation.

Within this framework, Berlinguer soon became in the eyes of many former militants and voters an icon, the incarnation of the best part of 
Italian communist history and tradition, the only political memory they could really treasure. At grassroots level this is proved, for example, by songs devoted to Berlinguer written by authors who were known for being very close to communist culture. 'I close my eyes and I think of you, sweet Enrico, in my heart you are alive and at my side', sang Italian pop singer Antonello Venditti in Dolce Enrico (Sweet Enrico, 1991), while a few years later the Emilian folk band Modena City Ramblers wrote a song chronicling Berlinguer's funeral which intoned: 'An entire people holds its breath staring at the coffin placed under the stage and the large picture. The city is a sea of red flags, flowers, tears, and farewells.' (I funerali di Berlinguer, 1994). Both songs show how the figure of Berlinguer was part of the collective imaginary and was likely to arouse strong emotions as early as the 1990s. They are also evidence of the rather nostalgic and rhetorical fashion Berlinguer was remembered for and passed down to future generations.

Enrico Berlinguer, was, as said above, the only thing the postcommunist left was left with. And it was not an embarrassing legacy. Unlike Togliatti, Berlinguer had not personally lived through the period of the Third International and therefore he could not be associated with any Stalinist misdeeds. Equally, he could not be seriously accused of having been a servant of Moscow, as Berlinguer was the leader who had finally broken the PCI's historic link with the Soviet Union, in December 1981, with the so-called strappo (the split or tearing apart). ${ }^{9}$ Lastly, the question of his loyalty to Italian democratic institutions could hardly even be posed. Under the leadership of Berlinguer the PCI had in fact resolutely fought both red and black terrorism. For all these reasons, the historiographical debate about Berlinguer had been less controversial and certainly not as polemical as the one about Togliatti, in the early 1990s.

In the mid-1990s, however, several left-wing authors focused on what conception of democracy had informed Berlinguer's political strategies and investigated whether such conceptions and strategies had actually helped the development of Italian democracy, or at least its survival, as was generally believed, or had rather produced a delay in its modernisation. In this respect, the most frequently analysed among Berlinguer's policies was the so-called Compromesso storico. The compromesso storico 
strategy, which Berlinguer had launched in 1973, consisted of a proposal for a grand alliance with Democrazia Cristiana, with the aim of driving the country out of the current political and economic crisis and to introduce 'a few elements of socialism' in the national economic system. Such a policy, which was in many respects consistent with the spirit of Togliatti's 'Salerno Turn' policy, appeared to many post-communist historians writing in the post-communist age as a hint of an enduring misconception of democracy by the communist leadership: Berlinguer, as well as Togliatti, did not believe in that alternation in power which normally characterises the political praxis of Western style democracies. ${ }^{10}$ Because of his communist cultural background, Berlinguer was the bearer of a vision which was far from the liberal idea of democracy: his fidelity was neither to the Western style democratic system nor, in many respects, to the democratic institutions themselves, but rather to a specific and historically determined form of democracy, the Italian one, whose functioning was based on a continuous bargaining process among the principal anti-fascist political parties. ${ }^{11}$

This conception of democracy has been defined as consociativa - the expression consociativismo can be translated as the practice of involving the opposition in government through a series of compromises - or organicistica (organicistic), aimed at an agreement between the masses which would allow a harmonious and non-conflicting management of politics' ${ }^{12}$ In order to fully understand the motivations for such criticisms of Berlinguer's political legacy, it is important to point out how these were specifically addressed from 1996 onwards. Before that year, while Togliatti was hitting the headlines on a nearly daily basis, Berlinguer had been virtually ignored by press and historians, with the exception of some acute remarks contained in the 1992 book by Gallerano and Flores (see in particular pp237-256), and a few other publications, most of them of a commemorative character, by former members of the communist party written for the tenth anniversary of his death. ${ }^{13}$ In 1996, the centre-left coalition, led by the PDS, won the election and got into government for the first time since 1947. Such an achievement urged left-wing historians and intellectuals to reconsider the Berlinguer years, when the Italian left had missed an historic opportunity to get into the government, following the election of 1976. 
The aim of the investigation was to detect what was so ideologically wrong with Berlinguer's policies that they were removed from the political heritage of the PDS. The titles of some of the books published in those years are very revealing in this respect: Alberto Asor Rosa's $L a$ sinistra alla prova (The left-wing put to the test, 1996); Aldo Schiavone's I conti col comunismo (Squaring the accounts with communism, 1997) and, especially, Miriam Mafai's Dimenticare Berlinguer (Let's forget Berlinguer, 1996), which sounded like an unequivocal exhortation to her fellow members of the PDS. As we pointed out, Berlinguer's failure was in the first instance ascribed to his lack of adhesion to Western style democratic principles. In 1996, however, many former communist politicians went much further in criticising the political choices Berlinguer had made during his leadership. They actually instituted what has been defined as 'a kind of posthumous legal proceeding'14 against Berlinguer, releasing very critical statements about virtually every aspect of his political activity, for example his famous Eurocommunism, that is the attempt to promote a new, non-Soviet aligned, version of communism which would be suitable for Western countries. ${ }^{15}$ The crescendo of criticism eventually provoked a public protest by Berlinguer's daughter on the front page of l'Unità, in November 1996. She accused the left-wing leaders of using her father as a scapegoat for their communist past, after having capitalised on his memory as long as this was politically convenient. ${ }^{16}$ This looked very much like a sort of unresolved political Oedipus complex, as all the leaders of the PDS had been politically formed during Berlinguer's age: they were - to quote the title of a book by one of them - I ragazzi di Berlinguer (Berlinguer's boys), and they were therefore murdering their political father. ${ }^{17}$

Only conjectures can be made about the reasons which urged the post-communist leadership to suddenly distance itself so resolutely from the PCI's most prestigious leader. In spite of what he had done to detach the PCI from the Soviet Union, Berlinguer had been a communist and had remained so until his death, as proved, for instance, by Eurocommunism. The PDS was struggling to make public opinion forget its communist roots and therefore Berlinguer was to be publicly blamed. Furthermore, there were specific aspects of Berlinguer's political activity 
that were an embarrassment for the PDS. The campaign for the moralisation of the political system that Berlinguer had launched at the beginning of the eighties, the so-called questione morale, especially represented a potentially harmful legacy for the PDS, as it could be seen as a source of inspiration for the mani pulite investigation. ${ }^{18}$ This could endorse the right-wing reading of mani pulite as a political plot set up by the post-communists in order to wipe out their political adversaries and get into national government. Overall, Berlinguer appeared to belong to a different age. His pleas to the workers to maintain a sober and frugal life style and his statements against consumerism sounded outdated and anti-modern. Even his demureness seemed rather old-fashioned in the boisterous Berlusconi age.

However, in politics, just as in war, when a position is left undefended, it is promptly occupied by the enemy. And so it was for the political legacy of Berlinguer. Because the post-communist leadership decided to get rid of Berlinguer's political heritage, his ideas were taken over by other political groups and individuals, who in many cases had little to share with the institutional left. Most notable, in this respect, is the use of Berlinguer's questione morale as a club with which to hit the post-communist left. The initiator of this polemical reprisal of the questione morale was the right-wing journalist Marco Travaglio, a champion of public morality and fierce adversary of Silvio Berlusconi. Over the years, Travaglio has produced a quite successful and influential narrative according to which the post-communist Italian leaders have been progressively going down the slippery slope of moral compromise, to the point of turning the once respectable PCI into something not much dissimilar to the much-hated Forza Italia, the political formation created by Silvio Berluconi.

In order to expose the alleged corruption of the heirs of the PCI, Travaglio would quote on more than one occasion the very words pronounced by Enrico Berlinguer in 1981, in a famous interview about corruption of Italian political parties with journalist Eugenio Scalfari. Travaglio quoted that interview, for example, in Promemoria, a sort of political play written by Travaglio himself and with which he toured the Italian theatres in 2009: 
The parties today are, above all, machines of power and clientelism. Their ideas, ideals and programs are either few and far between or just simply vague. As for fine sentiments and civic passion - zero. They manage the most disparate, contradictory and at times shady interests - and always without any relationship whatsoever to emerging human needs or the public good. Their organisational structures are shaped according to this model. They are no longer organisers of people, aimed at creating civic maturity and a sense of initiative: they are rather federations of factions, camarillas, each one with a boss and sub bosses.

These words by Berlinguer have been repeated countless times over the last twenty years by many political actors, commentators and journalists, eventually turning into a sort of mantra to be repeated by all those who are not happy with the moral standards (which are, in truth, far from being high) of Italian politicians. It is not adventurous to claim that Berlinguer's words, and the discontent they helped to fuel, played a part in the rise of one of the most staunch political adversaries of the post-communist Left, the Five Star Movement, a political formation created a few years ago by stand-up comedian Beppe Grillo. Grillo put the moralisation of public life at the top of his political agenda and even tried to capitalise on the memory of Berlinguer by claiming that the members of the five star movement were to be regarded as the true political heirs of the great communist leader, for their indefatigable action against corruption: 'Berlinguer's dreams live on thanks to us!', he claimed in May 2014. ${ }^{19}$

While many commentators and politicians of various political backgrounds have made of the former secretary of the PCI a symbol of the morality which is today lacking in Italian politics, others, more markedly left-wingers, have nourished another kind of nostalgia of Berlinguer: the nostalgia for the last revolutionary leader of the Italian left. This second type of nostalgia reframes the classic evaluations of the political work of Berlinguer by left-wing intellectual circles of the 70s, reaching opposite conclusions. According to this reframing, Berlinguer is not anymore the father of the compromise with moderate forces through the Compromesso storico policy. He is, instead, the man who worked out how socialist ideals could survive, in some form, in Western Europe and tried to make this 
perspective come true, albeit failing in his endeavour. This interpretation is the outcome of a new reading of two famous speeches by Enrico Berlinguer which address the concept of austerity. The first, 'Austerity: a chance to change Italy', was pronounced at a meeting of intellectuals and artists on the 15th January 1977.

The second speech was pronounced two weeks later in front of a quite different but, with respect to Berlinguer's strategy, equally important audience: a meeting of industrial workers. ${ }^{20}$ In those speeches Berlinguer formulated his own definition of austerity, which sounded utterly original. According to the leader of the Italian Communist Party austerity was: 'a necessary choice and, at the same time, a path to salvation for Western people $[\ldots]$ the working class tool to finally overcome a system that is showing its weakness, a system characterised by waste and dissipation, unbridled individualism and senseless consumerism. Austerity means responsible behaviour, efficiency and social justice'. Berlinguer claimed:

We have to abandon the illusion that a lifestyle based on an unquestioned growth of private consumption will be forever tenable.

Berlinguer's proposals met quite soon insuperable opposition, not only from the government and the right-wing parties, but even from the leadership and the rank and file of the communist party itself and, noticeably, from the student movement which was, at the time, quite strong and a real protagonist of the Italian political panorama. According to the student movement, Berlinguer's words on austerity were purely motivated by the desire to finally get to a political alliance with the DC, and thus realise the Compromesso storico policy. In other words, by selling down the river the interests of the working class, Berlinguer hoped to obtain, in return, a share of power by way of participation in the Government. This interpretation of Berlinguer's austerity, and of the Compromesso storico policy, was part of the left-wing reading of Berlinguer's policy for many years, both in Italy and abroad.

However, following the long and lingering debt crisis which Italy faced from the early 1990s, and especially after the deep economic crisis which has hit the country since 2008, many left-wing commentators and ordi- 
nary citizens came to the conclusion that Berlinguer's vision of austerity might have been, after all, farsighted. For example, as early as 1996, the famous political commentator Michele Serra wrote in l'Unità, the official newspaper of the PDS, that Berlinguer's plea to the Italian workers to embrace austerity as a form of resistance against the social and moral degeneration induced by a broken financial system were among the few truly revolutionary words ever pronounced by an Italian political leader. ${ }^{21}$ In May 2009, historian and PD MP Miguel Gotor came to very similar conclusions in a speech pronounced in the Senate, when he claimed that the Italian left had to be brave enough to open itself up to new, unexplored and apparently outlandish possibilities, just as Berlinguer had done in 1977, when he had imagined that the solution to the economic crisis would pass through a resolute struggle against consumerism. ${ }^{22}$ According to these interpretations, Berlinguer had foreseen the crisis of the system, and he had tried to save the western societies by moralising them, while saving, at the same time, the soul of the Italian workers by shielding them from rampant consumerism. There is, of course, a certain dose of moralism in these readings. On the other hand, a certain degree of moralism seems to be part of every contemporary reading of the political legacy of Enrico Berlinguer. This is visible not only in the abovementioned revival of the questione morale, but also in what we could define as popular, spontaneous, grassroots nostalgia of Berlinguer.

This third kind of nostalgia can be found in a variety of websites, blogs, and comments on Youtube. There are websites devoted to the life and thought of Enrico Berlinguer created by people who were not even born when Berlinguer died. This is the case, for example, with the website www.enricoberlinguer.it, founded by a student in 2009 , and which is today a most valuable online repository of documents, photos, opinions, articles, and videos regarding the communist leader. Every video depicting Berlinguer on Youtube is invariably welcomed by dozens of comments praising the integrity, the moral status and the political inventiveness of Berlinguer as opposed to the lack of principles and incapacity of modern politicians. These are, of course, purely sentimental statements, lacking almost entirely historical contextualisation and political analysis of the life, times and policies of Enrico Berlinguer. And yet, they are indicative of widespread feelings. 
To many ordinary citizens Berlinguer is the symbol of a lost Italy, an Italy which people recollect, or imagine, as more moral, socially more integrated, more passionate, and definitely wealthier than present day Italy; in short, a happier country. These sensations are arguably linked to the general bewilderment produced by globalisation over the last decades, many aspects of which took Italian politics, Italian society, and overall the Italian economic system utterly by surprise, as proved by the costly and prolonged economic and political crisis the country is experiencing. Berlinguer also keeps influencing pop culture. For example, cartoonists Elettra Stamboulis and Gianluca Costantini recently published a graphic novel on Berlinguer, Arrivederci Enrico (Goodbye Enrico, 2013). This shows how the myth of Berlinguer has proved adaptable to the most recent formats promoted by the cultural industry.

To summarise what we have been discussing in this paper, the nostalgia for Enrico Berlinguer is multifaceted in Italy, and it is principally the outcome of a sort of political repression by the post-communist left. Utterly disregarding the suggestion made in l'Unità by historian Patrick McCarthy, in 1996, to treasure the positive image which Berlinguer retained in people's eyes, the post-communist Italian leaders preferred to distance themselves as much as possible from the great communist leader, so that public opinion would forget the historical links between the new post-communist left and the PCI. ${ }^{23}$ This left a void, which was soon filled by other players. The questione morale, the piece de resistance of the final phase of Berlinguer's career, was relentlessly waved against the post-communist left. The Compromesso storico policy, repudiated by the official party historians as fundamentally flawed as far as the conception of democracy was concerned, was positively reassessed by some left-wing authors, who regarded it as based on a prescient anticipation of what was to come on both the economic and political plane. Finally, the lack of an official elaboration of Berlinguer's legacy by the PDS, as well as by the subsequent DS (Democratici di Sinistra), paved the way for an unchecked multiplication of informal memorialisation of Enrico Berlinguer, especially on the web. This has a variety of manifestations, but also a common denominator: Berlinguer is the symbol of happy days, he embodies a pre-globalisation Italy, which many regard as better in almost every respects, and which is irremediably lost. 
Perhaps sensing these widespread feelings, or perhaps in order to finally dispossess the political adversaries of a polemical tool, the Partito Democratico, a party established in 2007 as the last embodiment of the institutional left, has taken some steps to regain ownership over the memory of Berlinguer. In view of the $30^{\text {th }}$ anniversary of Berlinguer's death, for example, many councils ruled by the PD decided to name streets and squares after Enrico Berlinguer. ${ }^{24}$ Major leaders of the PD publicly paid homage to his memory by releasing very positive, although rather generic, statements about his political figure. The leader of the party and Prime Minister Matteo Renzi claimed: '(Berlinguer's) testimony of political engagement in the service of the common good remains; a political engagement in which his ethical values were never distinct from his ideals', a statement which, while hinting obliquely at Berlinguer's communist values, put the spotlight on his human qualities. ${ }^{25}$

In order to completely appreciate the sense of Berlinguers' reappropriation on the part of the PD leadership, it is worth pointing out that, nowadays, Berlinguer can no longer represent a political embarrassment for the PD, not only because too much time has passed for Berlinguer's communist beliefs to be effectively used as a polemical tool in the political arena, but also because the PD only partially roots itself in the communist tradition, being the result of the merging together of the post-communist and Christian democrat political traditions. Matteo Renzi, for instance, belongs to the latter.

The most comprehensive attempt to reconcile the PD with its illustrious predecessor on the cultural plane has been perhaps attempted by former leader of the DS Walter Veltroni, who recently released a filmdocumentary about Berlinguer. The film in question, Quando c'era Berlinguer (2014), is a sort of 'operation nostalgia', endorsing many of the assumptions the public share about Berlinguer: he was fundamentally a decent man and an honest politician, whose political actions were always motivated by the pursuit of the greater good. The film also proposes a non-conflictual reading of the Compromesso storico policy. For example, it does not address the issue of what conception of democracy informed the most famous of Berlinguer's political strategies, nor does it express a judgement on whether the policy in itself was right or wrong. 
The film's bottom line with respect to the Compromesso storico is that it must be judged against the background of the political and social reality of 1970s Italy. Its implementation was somehow required, and its failure was ineluctable. ${ }^{26}$ This set of initiatives by the PD are quite clearly aimed at constructing a sugarcoated, and rather 'anaemic', to use an expression by university professor and film critic Augusto Sainati, version of Berlinguer, one which can be unhazardously welcomed in the Pantheon of the political fathers of the PD. ${ }^{27}$ This, in turn, has provoked a reaction by those who don't want public opinion to forget the communist and revolutionary imprinting of Berlinguer's thought and policies. ${ }^{28}$

In conclusion, the nostalgia of Enrico Berlinguer does not seem at risk of fading as Italy progresses in the new century. The struggle over his memory and legacy is and remains open. Whether Berlinguer will be passed on to future generations as an illustrious member of the Pantheon of the institutional left, or whether he will be a symbol for those who are, for one reason or another, in disagreement with the current state of things, remains to be seen.

\section{Notes}

* The authors would like to thank Dr Giuliana Tiripelli who gave a valuable contribution to the initial definition of the ideas which are the basis of this paper. The phrase 'We all miss you' is an adaptation of the front-page headline of l'Unità ('Mancherai a tutti'), 13 June 1984 - the day of Berlinguer's funeral.

1 Donald Sassoon, One Hundred Years of Socialism: the West European Left in the Twentieth Century, London: I. B. Tauris, 1997, p590.

2 See, for example, https://www.youtube.com/watch?v=pI5jKV8Smao, which shows RAI 1's coverage, with voice-over by Bruno Vespa. The second comment on the video reads: 'Where are you, great, honest man? All that is left is your memory, nothing else'.

3 See, for example, former Romanian dictator Nicolae Ceaușescu's revival in present day Romania, which is discussed in various studies, including Diana Georgiescu 'Ceauşescu Hasn't Died. Irony as Countermemory in Post-Socialist Romania', in Maria Todorova and Zsuzsa Gille (Eds.) Postcommunist Nostalgia, New York; Oxford: Berghahn Books, 2010. 
4 David Kertzer, Politics and Symbols. The Italian Communist Party and the Fall of Communism, New Haven: Yale University Press, 1996. On the PCI's transition to post-communism see also John M. Foot 'The Left opposition and the Crisis: Rifondazione Comunista and La Rete', in Stephen Gundle and Simon Parker (Eds) The New Italian Republic: From the Fall of the Berlin Wall to Berlusconi, London: Routledge, 1996, pp173-189.

5 A 1991 song by singer and song writer Giorgio Gaber, entitled Qualcuno era comunista (Someone used to be a communist), effectively described the psychological mechanisms which were at work behind active militancy in the Italian Communist Party: 'Someone used to be a communist because he needed a push toward something new, because he was willing to change every day, because he felt the need for a different morality, even though maybe it was just a heartbeat, an illusion, a dream, it was just an impulse, a desire to change things, to change life'.'

6 See Gianluca Fantoni 'After the fall: politics, the public use of history and the historiography of the Italian Communist Party (1991 - 2011)' in Journal of Contemporary History, 49 (4), 2014, pp815-836.

7 The traditional interpretation of Gramsci's theory of hegemony by the PCI leadership was that Gramsci had suggested that the seizure of power by the working class in a western country had to be preceded by a period in which the party of the working class would manage to impose its vision and ideas on society, making them hegemonic. This reading, however, has been challenged by other scholarly interpretations; see for example Peter Thomas, The Gramscian Moment. Philosophy, Hegemony and Marxism, Chicago: Haymarket. 2010, pp159-241,.

8 An analysis of the vast literature on Togliatti's elaboration, or rather exploitation, of Gramsci's thought is beyond the scope of the present paper, but see Stephen Gundle 'The Legacy of the Prison Notebooks: Gramsci, the PCI and Italian Culture in the Cold War Period' in Christopher Duggan and Christopher Wagstaff (eds.) Italy in the Cold War. Politics, Culture and Society (1948 - 1958), Oxford: Berg, 1995, pp639-662.

9 Francesco Barbagallo, Enrico Berlinguer, Rome: Carocci, 2006, pp409 10.

10 See Giuseppe Vacca, Vent'anni dopo. La sinistra tra mutamenti e revisioni, Turin, Einaudi, 1997, pp153-156. 
11 See Luciano Cafagna, Una strana disfatta. La parabola dell'autonomismo socialista, Venice: Marsilio, 1996, pp50-51.

12 See Piero Ignazi 'Italy in the 1970s between Self -Expression and Organicism' in Anna Cento Bull and Adalgisa Giorgio (eds) Speaking out and Silencing. Culture, Society and Politics in Italy in the 1970s, London: Legenda, p10. For a discussion of consociativismo see Nicola Gallerano and Marcello Flores, Sul PCI. Un'Interpetazione storica, Bologna: Il Mulino, 1992, p245.

13 See, in particular, Massimo D’Alema and Paul Ginsborg, Dialogo su Enrico Berlinguer, Firenze: Giunti, 1994; Walter Veltroni, La Sfida Interrotta, le Idee di Enrico Berlinguer, Milan: Baldini \& Castoldi, 1994; Mario Tronti, Berlinguer: il principe disarmato: con una scelta di testi del leader del Pci su questione morale, riforma della politica e ruolo dei partiti, Rome, Sisifo, 1994, and Aldo Tortorella, Berlinguer aveva ragione. Note sull'alternativa e la riforma della politica, Rome: Edizioni di Critica marxista, 1994.

14 Chiara Valentini, Berlinguer. L'eredita Difficile, Rome: Editori Riuniti, 1997, pVII.

15 For an international perspective on Eurocommunism see Maude Bracke, Which Socialism? Whose Détente?: West European Communism and the Czechoslovak Crisis of 1968, Budapest and New York: Central European University Press, 2007, pp323-359.

16 Renzo Trivelli, L'impegno e la memoria. Anni con Enrico Berlinguer, Soveria Mannelli (CZ): Rubettino, 2001, p23.

17 Pietro Folena, I ragazzi di berlinguer. Viaggio nella Cultura Politica di una Generazione, Milan: Baldini \& Castoldi, 1997.

18 Mani pulite (Operation clean hands) is the name given to the investigation of corrupt politicians carried out by investigation magistrates during the early 1990s. See Paul Ginsborg, Italy and its Discontents. 1980 - 2001, London: Penguin, 2001, pp249-284.

19 http://www.repubblica.it/speciali/politica/elezionieuropee2014/2014/05/ 22/news/m5s_fico_processi_li_fanno_i_magistrati-86843226/.

Accessed on 20/10/2015.

20 The two speeches are in Enrico Berlinguer, Austerità: occasione per trasformare l'Italia. Le conclusioni al convegno degli intellettuali (Roma, 15/01/77) $e$ all'assemblea degli operai comunisti (Milano, 30/01/77), Rome: Editori Riuniti, 1997. 
21 Michele Serra 'Berlinguer', in l'Unità, 20/11/1996, front page.

22 http://miguelgotor.italianieuropei.it/2009/05/intervento_alla_camera_ dei_dep/. Accessed on 20/10/2015. Gotor is also the editor of a book about Berlinguer published in 2013: see Enrico Berlinguer, La passione non è finita, Turin: Einaudi. An endorsement of Berlinguer's austerity in recent years also came from Lucio Magri, a left-wing thinker who, in many other respects, had forcefully criticised Berlinguer's policies as leader of the PCI: see Il sarto di Ulm. Una possibile storia del Pci, Milano: Il Saggiatore, 2011, p315.

23 Patrick McCarthy, 'Perché dobbiamo dimenticare Berlinguer?', in l'Unità, 20/11/1996, p. 2.

24 See for example Milan, a square in 2012; Florence, a square in 2014; Rome, a square in 2014; Naples, a square in 2014; Rieti, a square in 2014, Reggio Emilia, a park in 2015, and many others in smaller cities and towns.

25 http://www.ansa.it/english/news/politics/2014/06/11/politicianspay-homage-to-berlinguer_dca3116e-476b-4cea-8fe7-d0d14f496375. html

26 This is not the only film-documentary devoted to Enrico Berlinguer and released in the 30th anniversary of his death. See also, La voce di Berlinguer, by Teho Teardo, and Mario Sesti, distributed by Istituto Luce - Cinecittà, and principally dealing with the questione morale.

27 http://www.ilfattoquotidiano.it/2014/04/01/quando-cera-berlinguer-ilfilm-senza-sangue-di-veltroni/933175/

28 See, for example, a book recently published by Guido Liguori, Berlinguer rivoluzionario (Berlinguer as a revolutionary). Il pensiero politico di un comunista democratico, Rome: Carocci, 2014. 